\title{
Impact of selection felling on Ecosystem health of Kottiyoor Reserved Forest, Western Ghats of India
}

\author{
ARR Menon ${ }^{1}$ and Abhilash ES ${ }^{2}$
}

${ }^{1}$ Scientist, Kerala Forest Research Institute, Peechi, Kerala, India

${ }^{2}$ Assistant Professor, P.G. Department of Botany, Sree Narayana College, Nattika, Thrissur, Kerala.

\begin{tabular}{l}
\hline Original Article \\
\hline Corresponding Author \\
Dr. Abhilash ES \\
Assistant Professor, P.G. Department of Botany \\
Sree Narayana College \\
Nattika, Thrissur, India \\
Email: abhies@gmail.com \\
Abstract
\end{tabular}

Phytosociological analysis reveal that Palaquium ellipticum and Knema attenuate are the common dominant species present with their co- dominants such as, Memecylon decanese, Macranga peltata, Vateria indica etc. More than fifty percent of the established seedlings are contributed by the dominant and co-dominant species. Thus there is a gradual shift of natural evergreen species composition to the more light demanding moist deciduous elements.

Key Words: Selection felling, Phytosociology, IVI, Density, Frequency.

\section{Introduction}

The commonest silvicultural system adopted is selection system where the exploitable girth class, felling cycle and number of trees to be extracted in a unit area is the cardinal factors involved. Although forest working plans prescribe guidelines for extraction, very often they are not strictly adhered to, endangering the continuity of operation. The selection system was used for management of tropical wet evergreen forests of the Western Ghats of India. It involves the selective removal of mature or over mature trees of the forests so that sustainability of the forest resources is not endangered. The girth limit prescribed for extraction was generally above $180 \mathrm{~cm} \mathrm{GBH}$ and the felling cycle is usually 30 years. Under this system, maximum number of trees to be removed from any one- hectare varies from 8 to 12 individuals. Due to increase in demand of wood, at times, a shorter felling cycle is adopted and sometimes the number of trees extracted is also beyond the prescriptions of working plans, thus endangering the canopy continuity. Thus the selective felling system prescribed earlier for the management of forests of Kerala has both direct and indirect impact on ecosystem, especially affecting the regeneration of forest trees. Hence in the present study an attempt was made for evaluating the previous felling operations with respect to forest regeneration.

\section{Material and Methods}

The phytosociological evalutation was done using stratified random sampling method. The study area chosen was Kottiyoor reserved forest which is located at the Southern part of India which had been undergone selective logging up to 1983 . Based on vegetation type and density status, quadrates were laid out throughout the study area. The size of the quadrate was 1 ha for tress, $5 \mathrm{~m} \times 5 \mathrm{~m}$ plots for saplings and seedlings. The primary analysis of the vegetation was done using the method of Muller- Dombois and Ellenberg (1978).

\section{Results:}

The tree vegetation in Non Selection felled area dominated by five species with respect to IVI is Persea macrantha (29.45), Palaquium ellipticum (29.29), Vateria indica (23.94) - IVI in paranthesis. (Table-1).

\section{* Table-1. Phytosociological parameters selected tree species of Non Selection felled area.}

\begin{tabular}{|l|c|c|c|c|c|c|c|c|c|}
\hline Species & D & F & RD & RF & AB & BA & RBA & AB/F & IVI \\
\hline Drypetus elata & 550 & 100 & 10 & 6.67 & 5.50 & 537.24 & 3.55 & 0.055 & 20.22 \\
Palaquium ellipticum & 750 & 100 & 13.64 & 6.67 & 7.50 & 1359.53 & 8.98 & 0.075 & 29.29 \\
\hline Persea macrantha & 100 & 50 & 1.82 & 3.33 & 2.00 & 3676.99 & 24.290 .040 & 29.45 \\
Syzigium cuminii & 400 & 100 & 7.27 & 6.67 & 4.00 & 706.61 & 4.67 & 0.040 & 18.61 \\
\hline Vateria indica & 1000 & 50 & 18.18 & 3.33 & 20.00 & 366.74 & 2.42 & 0.400 & 23.94 \\
\hline Sterculea guttata & 50 & 50 & 0.91 & 3.33 & 1.00 & 114.86 & 0.76 & 0.020 & 5.00 \\
\hline
\end{tabular}


V)raPJËESD

Drypetus elata, Palaquium ellipticum and Syzygium cumini are highly dense in the area. There are 27 species recorded of which Persea macrantha is having highest basal area (3676.99).

As in the case of selection felled area fifty species / ha area was recorded. The dominant species with respect to IVI above 10 are Myristica dactyloides, Knema attenuate, Drypetes elata, Vitex altissima, Ixora brachiata etc. (Table-2).

*Table-2. Phytosociological parameters of selected tree
species of Selection felled area.
\begin{tabular}{|l|c|c|c|c|c|c|c|c|c|}
\hline $\begin{array}{l}\text { Species } \\
\text { Carallia brachiata }\end{array}$ & 11.11 & 11.11 & 0.24 & 0.65 & 1.00 & 3920.32 & 9.62 & 0.090 & 10.51 \\
\hline Drypetus elata & 400 & 44.44 & 8.47 & 2.60 & 9.00 & 835.27 & 2.05 & 0.203 & 13.12 \\
\hline Hopea parviflora & 77.78 & 44.44 & 1.65 & 2.60 & 1.75 & 2524.37 & 6.20 & 0.039 & 10.44 \\
\hline Ixora brachiata & 288.89 & 66.67 & 6.12 & 3.90 & 4.33 & 163.35 & 0.40 & 0.065 & 10.41 \\
\hline Knema attenuata & 388.89 & 77.78 & 8.24 & 4.55 & 5.00 & 334.37 & 0.82 & 0.064 & 13.60 \\
\hline Myristica dactyloides 422.22 & 77.78 & 8.94 & 4.55 & 5.43 & 445.87 & 1.09 & 0.070 & 14.58 \\
\hline Vitex altissima & 133.33 & 55.56 & 2.82 & 3.25 & 2.40 & 2027.89 & 4.98 & 0.043 & 11.05 \\
\hline Melia dubia & 11.11 & 11.11 & 0.24 & 0.65 & 1.00 & 114.86 & 0.28 & 0.090 & 1.17 \\
\hline
\end{tabular}

Species with high basal area are Carallia brachiata, Vitex altissima and Hopea parviflora (Basal area more than 2000).

Myristica dactyloides, Knema attenuate, Dipterocarpus indica and Drypetus elata are having high density.

Non selection felled area comprises few species (11) at the sapling stage (Girth above $10.1 \mathrm{~cm}$ ) and the typical evergreen species like Drypetes elata, Vateria indica, Palaquium ellipticum are dominant. Thirteen species recorded in the seedling stage of which Syzygium calophyllianum, Syzygium mundagam and Vateria indica are the dominant species.

But selection felled area 26 species recorded in sapling stage of which three species viz. Myristica dactyloides, Strombosia zeylanica and Xanthophyllum arnottianum are the dominant species and also 33 species were noted in the seedling stage. Calophyllum polyanthum, Myristica dactyloides, Strombosea zeylanica and Xanthophyllum arnottianum etc. are the dominant species.

\section{Discussion:}

In this study area regeneration rate of non selection felled area was comparatively low with respect to selection felled area because the non selection felled area had been attained climax stage and the disturbed nature of selection felled area, gap formation etc resulted massive regeneration in the later areas.
Logging has a major impact on the structural and compositional development of the forests (Cannon et al.,1994; Johns, 1997; Pinard and Putz, 1996).The tall above ground biomass in the regenerating forest has not fully recovered to the level of primary forest even after 30 years of logging, even though theoretically possible. This study also throws light on the fact that the domination of Vitex altissima, Ixora brachiata etc which are the typical moist deciduous species changed the species composition of the earlier pristine tropical evergreen forest to secondary forest. The gap formation in forest is accelerated due to selective logging. Very little scientific evidence is available regarding the recovery process of ecosystem after logging. The changes in the structure of the canopy layer after logging will definitely affect the light spectrum on the forest floor and will eventually favours the growth of light demanding invading species like Macranga peltata, Anthocephalus spp., Trema orientalis etc., thus affecting the competitive relationships between saplings and seedlings (Lee et al.,1995). The creation of gaps in the dense over storey due to logging, gradually leads to a different species composition as observed in the present study.

\section{Conclusion:}

The selective logging system rests on the theory that sufficient medium sized trees can be retained during a harvest to contribute to the bulk of the next crop. Phytosociological analysis reveal that Palaquium ellipticum and Knema attenuate are the common dominant species present with their co-dominants such as, Memecylon decanese, Macranga peltata, Vateria indica etc. More than fifty percent of the established seedlings are contributed by the dominant and co-dominant species. Thus there is a gradual shift of natural evergreen species composition to the more light demanding moist deciduous elements.

\section{*Abbreviations used in the tables:}

$\mathrm{D}=$ Density, $\mathrm{F}=$ Frequency, $\mathrm{RD}=$ Relative Density, $\mathrm{RF}=$ Relative Frequency, $\mathrm{AB}=$ Abundance, $\mathrm{BA}=$ Basal Area, $\mathrm{RBA}=$ Relative Basal Area, IVI= Importance Value Index.

\section{Acknowledgments:}

The authors are thankful to Kerala Forest Department for Financial assistance and Director, KFRI for excellent support for the said study.

\section{References:}

Cannon, $\mathrm{CH}$., Peart, D.R., Leighton, $\mathrm{M}$ and Krtawinata, K. 1994. The structure of lowland rainforest after selective logging in West Kalimantan, Indonesia. J. For.Ecol. Manag. 67: 49-68.

Johns,A.G. 1995. Timber production and biodiversity conservation in tropical rainforests. Cambridge Univ. Press. Cambridge.225pp.

Asia Pacific Journal of Environment Ecology and Sustainable Development 2013;1:29-31

(An International Peer Reviewed Journal)Copyright (C) 2013 ATRFCE

Published online by NepJOL-INASP

www.nepjol.info/index.php/APJEESD 
Lee, S.S., Chan, S.T., Kirton, L.G., Lim, B.L., Ratnam, L., Saw, L.G and Francis, C. 1995. A guide book to Pasoh. FRIM Technical information handbook, Malasia, 73pp.

Pinard, M.A and Putz, F.E. 1996. Retaining forest biomass by reducing logging damage. Biotropica.28:278-295.

\section{Article Information}

\section{Article history}

Received

Received in revised form

Accepted
21 October 2012

10 November 2012

2 December 2012 